\title{
Neo-institutional Approach for Regional Economic Development: The Impact of Sociocultural Determinants
}

\author{
Submitted on 4/12/18, $1^{\text {st }}$ revision 8/1/19, accepted 28/1/19
}

\author{
Leyla Gamidullaeva ${ }^{1}$
}

\begin{abstract}
:
Purpose: The aim of this article is to analyze neo-institutional approach for regional development by identifying the impact of sociocultural determinants at regional level.

Design/Methodology/Approach: For regional economic development, it is required to identify sociocultural factors that contribute to (or impede) the innovative economic development of the regions by highlighting regions in which sociocultural factors will rather contribute (or rather impede) innovative development.

Findings: To take account of the influence of sociocultural factors on the effectiveness of institutional transformations, a system of indicators has been developed, evaluating sociocultural characteristics and behavioral attitudes of economic agents in a certain region. Practical Implications: The author developed recommendations before starting the process of institutional changes in a specific regional innovation system.

Practical Implications: The article formulates recommendations on the implementation of institutional changes in the region taking into account the sociocultural characteristics of the region's population.

Originality/Value: Sociocultural background is very important in terms of fine-tuning the process of institutional in regional level. As such it can be used for changes and to determine the specifics of their conduct in the regions of the Russian Federation.
\end{abstract}

Keywords: Neo-institutional approach, region, innovation system, sociocultural factors.

JEL code: D02, 043.

Acknowledgement: The Reported Study Was Funded by RFBR According to the Research Project No. 18-010-00204_A.

Paper type: Research article.

\footnotetext{
${ }^{1}$ Penza State University, Russia, e-mail: gamidullaeva@gmail.com
} 


\section{Introduction}

It is obvious that disproportions in the economic development of regions will always exist. All differences in the socio-economic situation of regions, especially in countries with a large territory, like Russia, will only worsen concurrently with the market economy development. Thus, the search for effective regional models of innovation systems is not only and not so much compensating as stimulating and developing, it is one of the defining aspects of institutional development throughout the world. According to Lapin (2006) there are two approaches for the term "region"; a general theoretical and a concrete practical one.

From the general theoretical point of view, the region is a community of people living in a certain territory, which is a part of a larger community. The region defines the ethnocultural identity of the resident population, while regional development is ensured by the activities of people who have common economic interests and are carried out within a specific institutional context. The community of the region "forms a close sociocultural environment for its members to live as individuals, motivates their actions; it is a place, where individuals mostly directly build complex mutual relations with each other, and indirectly with society. The region performs functions that are in part like those of the society, but at the same time they are specific. Each region has features that distinguish it from other regions of a given society, however it interacts with many of them" (Lapin, 2006).

From the concrete and practical point of view, the region should be considered a subject of the Russian Federation, which is a territorial unit of the "politicaladministrative, economic and sociocultural structure of the country". The legal status of the region is enshrined in the Constitution of the Russian Federation. "It is limited by the territory and is characterized by the peculiar nature of the environment, the ethno-religious composition of the population, its traditions, the specialization of production and exchange of goods and services, the number and structure of jobs, social infrastructure, level, quality of life of various segments of the population, organization of political and administrative management" (Lapin, 2006). Thus, the general theoretical approach to understand the essence and content of the concept of "region" makes it possible to identify the sociocultural aspects of the existing territorial community of people.

\section{Literature Review}

For the purpose of this study it is reasonable to use the neo-institutional theory which representatives are Coase (1993), North (1990), Menard (2001), Demsetz (1995), Williamson (1996), Auzan (2011), Popov et al. (2010). In general, the neoinstitutional theory mainly contributes to discovering the most important function of institutions, i.e., their ability to reduce uncertainty and transaction costs. The study of neo-institutionalism is centered on the individual establishing institutions. Its proponents call for reconsidering the vision of economics as a formalized science, that 
they reject methods of specific economic research, including marginalist and equilibrium analysis.

The cross-disciplinary nature of neo-institutional methodology makes it possible to reckon many more significant factors when studying the behavior of individuals. "It is impossible to understand how the economic system works, to analyze some problems arising in it, and to get the basis for developing policy recommendations without the concept of transaction costs, which is mostly absent in modern economics" (Coase, 1993). The set of institutions operating in society constitutes its institutional environment, creating the corresponding transactional relations, which influence the transaction costs of human activity and, as a result, form a system of positive and negative incentives. Indeed, deep understanding of the occurring social processes will determine the systemic essence of state actions and awareness of motives, exert a substantive impact on the system and its main elements, impose the idea of changes and ultimately rationalize the choice of economic agents. In this sense, the contribution of the neo-institutional approach is significant in broadening understanding of innovation processes. Thanks to neo-institutional methodology, the discussion of institutions and their impact on economic growth has been highlighted in the academic community.

In general, the institutional analysis rejects the existence of an intelligent individual. Understanding of the economic reality and trends in the development of economic systems requires knowledge of laws governing the functioning of institutions, which structure information about the reactions of economic agents to certain decisions and create models of expectations and evaluation.

Neo-institutionalism recognizes the limited rationality, in which economic agents operate. This rationality "suggests incomplete data generating subjective behavioral models of economic agents, which determines the formation of transaction costs. Their presence testifies to the imperfection of markets and certain government activities" (Sukharev, 2013). Consequently, economic policy should be aimed at cutting the transaction costs, as well as establishing institutions that contribute to their reduction. Nevertheless, in accordance with the neo-institutional approach, researchers should focus on exploring the impact of institutions and organizations on economic efficiency.

\section{The influence of sociocultural factors on innovation and institutional processes in the economic system}

The region is the place, where socialization of individuals takes place, behavioral habits of individuals are shaped, a system of incentives, motivating their actions and work, is created. It should be noted that there is often a gap between the norms of behavior enshrined in legal acts of various levels, and the basic values and behavioral attitudes of the population of a region. "The facts of deviating, criminal behavior of the inhabitants of the region appear as gaps between the values and norms of behavior 
of various segments of the population, in the language of institutionalism, between formal and informal institutions".

In our opinion, in most cases, the subjects of the Russian Federation, demonstrating a low level of economic development, have a problem of low efficiency in the use of the existing potential of economic agents and individuals. Such reserves can be formed due to the institutionalization of relevant social practices in these regions, which impede the development of innovative behavior of economic agents and individuals and support passive behavior. In contrast, in other regions, the established institutions and sociocultural factors (values and attitudes) support and stimulate innovative behavior.

Having a clear idea of the sociocultural background that has developed in a region is extremely important in view of the influence of the latter on the effectiveness of institutional reforms. To do this, first, it is necessary to develop a system of indicators that evaluate the sociocultural characteristics and behavioral attitudes of economic agents in a region. We shall take the classic approach of Hofstede (2001) as the basis for this research. It has been established that in collectivist countries, other things being equal, it is more common to maintain the current economic condition and block breakthroughs. A high level of collectivism is associated with a bonding type of trust (trust for a narrow circle of people), but it is often accompanied by a lack of generalized trust, which negatively affects economic growth due to high transaction costs.

Confidence in government and interpersonal trust has recently attracted more and more attention from the academic community as key factors for increasing collaboration in the economic system and ensuring economic growth. Short distance to authorities, social contract as the basis for interaction between government and society, provision of coordinated behavior through civil institutions following transparent and reproducible algorithms contribute to innovative development.The expression of collectivism values, in turn, is fraught with the problem of individual responsibility reduction, the risk of the "free rider problem" emergence. In accordance with the results of a study by Gulyanskaya (2008), most Russians consider themselves collectivists at a rate of $63 \%$. Current researches on the influence of sociocultural factors on innovation and institutional processes in the society are given in Table 1.

Thus, for the purpose of this study, it seems necessary: first, to identify those sociocultural factors that contribute to (or impede) the innovative economic development of the Russian regions; second, to highlight regions, in which sociocultural factors will rather contribute (or rather impede) innovative development; third, to formulate recommendations on the implementation of institutional changes in the region, taking into account the sociocultural characteristics of regional population. Sociocultural background is very important in terms of fine-tuning the process of institutional changes and determining the specifics of their conduct in the regions of the Russian Federation. 
Table 1. Analysis of the main studies of the influence of sociocultural factors on innovation and institutional processes in the society ${ }^{2}$.

\begin{tabular}{|c|c|c|c|}
\hline $\begin{array}{l}\text { Facto } \\
\text { rs }\end{array}$ & Authors & Research results & $\begin{array}{l}\text { General } \\
\text { conclusion for } \\
\text { the goals of the } \\
\text { present research }\end{array}$ \\
\hline \multirow{3}{*}{ 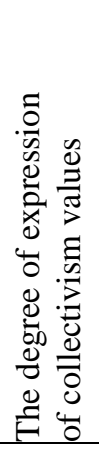 } & $\begin{array}{l}\text { Hofstede, } \\
\text { G. }\end{array}$ & $\begin{array}{l}\text { A significant positive correlation }(\mathrm{r}=0.82) \text { has } \\
\text { been revealed between the share of gross } \\
\text { national product per capita and the degree of } \\
\text { expression of individualism. }\end{array}$ & \multirow{3}{*}{$\begin{array}{l}\text { Collectivism } \\
\text { values } \\
\text { negatively } \\
\text { affect the } \\
\text { innovative } \\
\text { development of } \\
\text { the region. }\end{array}$} \\
\hline & $\begin{array}{l}\text { Gorodnich } \\
\text { enko, Y., } \\
\text { Roland, G. }\end{array}$ & $\begin{array}{l}\text { In collectivist countries, other things being equal, } \\
\text { it is more common to maintain the current } \\
\text { economic condition and block breakthroughs. }\end{array}$ & \\
\hline & $\begin{array}{l}\text { Herbig, } \\
\text { P.A., \& } \\
\text { Miller, J.C. }\end{array}$ & $\begin{array}{l}\text { Countries with a high level of individualism are } \\
\text { more successful in producing radical } \\
\text { innovations; collectivist countries - in producing } \\
\text { incremental innovations. }\end{array}$ & \\
\hline \multirow{3}{*}{ 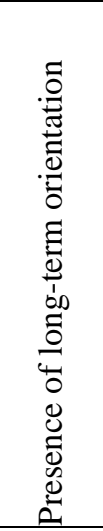 } & $\begin{array}{l}\text { Waarts, E., } \\
\text { \& Van } \\
\text { Everdinge } \\
\text { n, Y. }\end{array}$ & $\begin{array}{l}\text { The indicator of long-term orientation is } \\
\text { characterized by a positive relationship with } \\
\text { innovative development of the society. Long- } \\
\text { term orientation can stimulate productive activity } \\
\text { and long-term investments, which is of particular } \\
\text { importance for the production of innovations. }\end{array}$ & \multirow{3}{*}{$\begin{array}{l}\text { The factor of } \\
\text { long-term } \\
\text { orientation } \\
\text { contributes to } \\
\text { innovative } \\
\text { development of } \\
\text { the region }\end{array}$} \\
\hline & $\begin{array}{l}\text { Freytag, } \\
\text { A., \& } \\
\text { Renaud, S. }\end{array}$ & $\begin{array}{l}\text { Predictable, credible long-term economic } \\
\text { policies produce better results than short-term } \\
\text { policies with short-term goals. }\end{array}$ & \\
\hline & $\begin{array}{l}\text { Hofstede, } \\
\text { G. }\end{array}$ & $\begin{array}{l}\text { Countries whose populations have a long-term } \\
\text { orientation and a long-term planning horizon are } \\
\text { more likely to succeed in modernization } \\
\text { processes. }\end{array}$ & \\
\hline \multirow{3}{*}{ 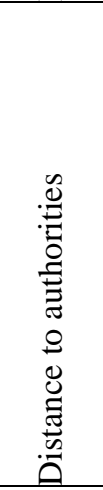 } & $\begin{array}{l}\text { Varsakelis, } \\
\text { N.C. }\end{array}$ & $\begin{array}{l}\text { The distance to authorities negatively affects } \\
\text { innovative development. Cultures with distant } \\
\text { authorities tend to be characterized by a } \\
\text { hierarchical structure of society and numerous } \\
\text { bureaucratic procedures. }\end{array}$ & \multirow{3}{*}{$\begin{array}{l}\text { The factor of } \\
\text { distance to } \\
\text { authorities } \\
\text { negatively } \\
\text { affects the } \\
\text { region's } \\
\text { innovative } \\
\text { development. }\end{array}$} \\
\hline & $\begin{array}{l}\text { Bouckaert, } \\
\text { G. }\end{array}$ & $\begin{array}{l}\text { In countries with distant authorities, the society } \\
\text { is less disposed to take an active part in the } \\
\text { reform process, it is interested in maintaining the } \\
\text { status quo and stability. }\end{array}$ & \\
\hline & $\begin{array}{l}\text { Polterovic } \\
\text { h, V.M. }\end{array}$ & $\begin{array}{l}\text { In such societies, it is more likely that } \\
\text { paternalistic sentiments will prevail, the neglect } \\
\text { of which will cause rejection of reforms. . }\end{array}$ & \\
\hline
\end{tabular}

\footnotetext{
${ }^{2}$ Compiled according to Auzan A.A. et al. Sociocultural factors of innovative development and successful implementation of reforms. Moscow 2017.
} 


\begin{tabular}{|c|c|c|c|}
\hline 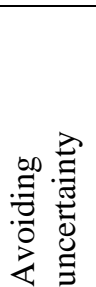 & $\begin{array}{l}\text { Bouckaert, } \\
\text { G. }\end{array}$ & $\begin{array}{l}\text { It creates additional obstacles for any (including } \\
\text { institutional) changes. The holding potential of } \\
\text { high uncertainty avoidance is lower in cases } \\
\text { where reforms are the result of a broad public } \\
\text { consensus, and their implementation was } \\
\text { preceded by a public discussion. }\end{array}$ & $\begin{array}{l}\text { The factor of } \\
\text { uncertainty } \\
\text { avoidance } \\
\text { impedes } \\
\text { regional } \\
\text { innovative } \\
\text { development. }\end{array}$ \\
\hline \multirow[b]{3}{*}{ 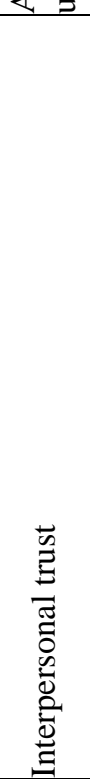 } & $\begin{array}{l}\text { Ruef, M. } \\
\text { Eklinder- } \\
\text { Frick, J., } \\
\text { Eriksson, } \\
\text { L.T., \& } \\
\text { Hallen, L. }\end{array}$ & $\begin{array}{l}\text { Bonding social capital (trust to a narrow circle of } \\
\text { people) serves as a barrier to innovative } \\
\text { development. It is the heterogeneity of the } \\
\text { network of participants in the innovation process } \\
\text { that is extremely important for generating } \\
\text { innovative ideas }\end{array}$ & \multirow{3}{*}{$\begin{array}{l}\text { The } \\
\text { interpersonal } \\
\text { trust factor is } \\
\text { fundamental in } \\
\text { the process of } \\
\text { innovative } \\
\text { development } \\
\text { with a positive } \\
\text { influence. }\end{array}$} \\
\hline & $\begin{array}{l}\text { Polterovic } \\
\text { h, V. M. }\end{array}$ & $\begin{array}{l}\text { A low level of interpersonal trust, that is, } \\
\text { bridging social capital, "has a direct impact on } \\
\text { management structures, creating the need for } \\
\text { additional control units." This increases } \\
\text { management costs and, especially, reform costs. }\end{array}$ & \\
\hline & $\begin{array}{l}\text { Woolcock, } \\
\text { M., \& } \\
\text { Narayan, } \\
\text { D. }\end{array}$ & $\begin{array}{l}\text { Bridging social capital contributes to innovative } \\
\text { development, acting as a factor reducing } \\
\text { transaction costs of communication and control } \\
\text { due to a high level of trust in people around. } \\
\text { Reducing costs allows you to establish effective } \\
\text { interaction between innovation process } \\
\text { participants, promoting dissemination of } \\
\text { knowledge and information }\end{array}$ & \\
\hline \multirow{2}{*}{ 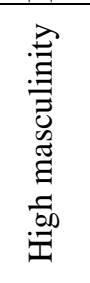 } & $\begin{array}{l}\text { Bouckaert, } \\
\text { G. }\end{array}$ & Positively effects ongoing institutional changes. & \multirow{2}{*}{$\begin{array}{l}\text { The social } \\
\text { masculinity } \\
\text { factor has a } \\
\text { positive effect } \\
\text { on the region's } \\
\text { innovative } \\
\text { development. }\end{array}$} \\
\hline & $\begin{array}{l}\text { Lebedeva, } \\
\text { N. M., } \\
\text { Tatarko, A. } \\
\text { N. }\end{array}$ & $\begin{array}{l}\text { Significant for innovative development, since } \\
\text { this factor is associated with a focus on results, } \\
\text { with the desire to transform the world around } \\
\text { you, instead of adapting to it }\end{array}$ & \\
\hline
\end{tabular}

Summarizing the above, the regional innovation system, in our opinion, is a complex open system that changes in time, uniting economic agents and relationships between them, regional sociocultural factors (values and behavioral attitudes), formal and informal institutions at the company level, at the level of regions and at the country.

It is important to distinguish between formal and informal institutions (rules, beliefs, norms and organizations). Formal institutions should be understood as statutory restrictions, benefits and preferences for innovative enterprises, specialized institutions for the protection of intellectual property, etc. Accordingly, informal institutions are a set of historically established, rooted in the minds and behavior of people various ideas, norms, values, beliefs, patterns, rules of behavior that are not formally fixed, but indirectly determine the nature and methods of relationships in the innovation system. 
In fact, it can be said that the development level of the formal institutional context of the region's innovation system is the region's innovation capacity, its potential. In turn, the regional receptiveness to innovations can be defined as the level of development of the informal institutional context of the innovation system. In systemic unity, the innovation capacity and receptiveness of the region form the institutional potential of the regional innovation system. The difference between the actual level of the institutional potential of the regional IS and the maximum possible one is the institutional context reserve of the regional innovation system. At the same time, the innovation receptiveness to a considerable extent depends on objective factors, for example, historical features of regional development.

Let us recall that before the census of the country's population in $1889,95 \%$ of the population of the Russian Empire at that time lived in the European part of the country, while it was only 5 percent beyond the Urals. At the same time, $75 \%$ of the population of the European part, being serf peasantry, lived on the income derived from agricultural activities. After the abolition of serfdom, having become community members, this population experienced enormous difficulties associated with agrarian overpopulation, hunger, very heavy taxes, etc. At that time, serfdom did not exist beyond the Urals either before or after the Stolypin reform. Only after the revolution, the regions of the Urals, Siberia and the Far East were populated by their main population for various reasons, including social programs and evacuation.

Thus, a more mobile, restless and risky part of the population of our country always lived outside the Urals. Of course, the Great Patriotic War also determined the differences between the European and Asian population of Russia through occupation, proximity to the front, evacuation from ones and mobilization of the population in other regions. Therefore, we can conclude that the characteristics of the population evolve under the influence of the external environment and are fixed in cultural and behavioral norms. Subsequently, these very norms and behavioral attitudes block, or vice versa, contribute to the innovative behavior of economic agents.

It should be said that the behavioral attitudes of the economic activity in Russia are the subject of numerous comparative studies. Some of these studies allowed us to describe and formalize the portrait of the Russian innovator. As stated in the study by Auzan et al. (2017), countries where elites do not work with the value orientations of the society have less chance of transition to a sustainable trajectory of economic development (for example, Argentina, Greece).

\section{Materials and methods}

Previously, we thoroughly considered those social and cultural factors that influence the innovative development of regions, which should be considered in our study. However, we managed to find not all data within the regional context of the study. As a result, the following social and cultural factors of the region were evaluated: 

1) interpersonal trust;
2) institutional trust (confidence in the public authorities);
3) collectivism;
4) sociocultural diversity (linguistic, ethnic, religious).

The latest data was taken from the study conducted by Auzan and his scientific group (2017) who developed indicators of the sociocultural diversity of regions, based on information about the linguistic, ethnic, religious diversity of the region's population. Research indicated little confidence in the authorities in Russia as a whole. A $68.1 \%$ of interviewees responded negatively to the question "In your opinion, do the authorities understand and take into account the interests of people like you or not?" (Table 2).

It is noteworthy that in Russia confidence is mainly of a bonding type (i.e. trust in a limited number of people, for example, on a national basis, on a family basis, etc.), as evidenced by the results of the surveys conducted by Levada Center, Public Opinion Foundation "Georating" and other agencies (Table 2 ) $^{3}$. These studies revealed that Russians tend to trust and help each other; however, this potential is not virtually exploited by public organizations.

In turn, such features of social relations lead to the formation of confined associations, when potential producers of public goods solely pursue interests of the narrow group to the detriment of public interests. For example, business associations are not engaged in their main activity, i.e. improving the institutional environment, but advance private interests of their group (benefits, preferences, etc.). Under these circumstances, public organizations can be guided by similar incentives (Table 2). Interaction with the authorities to improve their performance is not common in Russian society. It can be explained by the historical features of the state development, including the predominance of agriculture, serfdom, adherence to the Soviet principles of population welfare and restriction of rights. The analysis identified that interpersonal trust in the RF constituent entities is higher than confidence in the public authorities.

Table 2. Combination table of responses to the question "In your opinion, do the authorities understand and take into account the interests of people like you or not?",

\begin{tabular}{|l|l|l|l|l|}
\hline Response options & Frequency & Percent & $\begin{array}{l}\text { Nominal } \\
\text { percent }\end{array}$ & $\begin{array}{l}\text { Accumulated } \\
\text { percent }\end{array}$ \\
\hline Strongly agree & 837 & 2,5 & 2,5 & 2,5 \\
\hline Slightly agree & 5437 & 16,0 & 16,0 & 18,4 \\
\hline Slightly disagree & 12944 & 38,0 & 38,0 & 56,5 \\
\hline Strongly disagree & 10235 & 30,1 & 30,1 & 86,5 \\
\hline
\end{tabular}

\footnotetext{
${ }^{3}$ URL: www.levada.ru/press/2008031302.html.

${ }^{4}$ Sociological survey of the Public Opinion Foundation "Georating”. The database was provided by the Institute for Institutional Studies of the Higher School of Economics.
} 


\begin{tabular}{|l|l|l|l|l|}
\hline Neither agree nor disagree & 4576 & 13,4 & 13,4 & 100,0 \\
\hline No option & 9 &, 0 &, 0 & 100,0 \\
\hline Total & 34038 & 100,0 & 100,0 & \\
\hline
\end{tabular}

As an indicator for the level of interpersonal trust, we took an integral indicator calculated on the basis of the parameters: the proportion of people in the region who responded positively to the questions "How often can you find people around you, who are willing to unite in order to solve problems?"; "In your opinion, how often can you find people around you, who are ready to help each other?"; "Can you trust most people or should one be careful in dealing with people?"; "In your opinion, do Russian people today live in more agreement, solidarity or disagreement, disunity?" (Tables 3 and 4).

Table 3. Combination table of responses to the question "Can you trust most people or should one be careful in dealing with people?"

\begin{tabular}{|c|c|c|c|c|c|c|c|c|c|}
\hline \multicolumn{2}{|c|}{ Response options } & $\begin{array}{l}\text { Central } \\
\text { FD }\end{array}$ & $\begin{array}{l}\text { Northwest } \\
\text { ern FD }\end{array}$ & $\begin{array}{l}\text { Souther } \\
\text { n FD }\end{array}$ & $\begin{array}{l}\text { Volga } \\
\text { FD }\end{array}$ & $\begin{array}{l}\text { Ural } \\
\text { FD }\end{array}$ & $\begin{array}{l}\text { Siberia } \\
\text { n FD }\end{array}$ & \begin{tabular}{|l} 
Far \\
Eastern \\
FD
\end{tabular} & Total \\
\hline \multirow{2}{*}{$\begin{array}{l}\text { Most people } \\
\text { can be trusted }\end{array}$} & Number & 1572 & 1068 & 455 & 1124 & 405 & 780 & 857 & 6261 \\
\hline & $\%$ & 25,1 & 17,1 & 7,3 & 18,0 & 6,5 & 12,5 & 13,7 & 100,0 \\
\hline \multirow{2}{*}{$\begin{array}{l}\text { One should be } \\
\text { careful when } \\
\text { dealing with } \\
\text { people }\end{array}$} & Number & 7114 & 3689 & 1919 & 5646 & 1982 & 3501 & 2360 & 26211 \\
\hline & $\%$ & 27,1 & 14,1 & 7,3 & 21,5 & 7,6 & 13,4 & 9,0 & 100,0 \\
\hline \multirow[t]{2}{*}{ Not sure } & Number & 317 & 249 & 126 & 251 & 113 & 227 & 279 & 1562 \\
\hline & $\%$ & 20,3 & 15,9 & 8,1 & 16,1 & 7,2 & 14,5 & 17,9 & 100,0 \\
\hline \multirow[t]{2}{*}{ No option } & Number & 1 & 0 & 0 & 1 & 0 & 1 & 1 & 4 \\
\hline & $\%$ & 25,0 & 0,0 & 0,0 & 25,0 & 0,0 & 25,0 & 25,0 & 100,0 \\
\hline \multirow[t]{2}{*}{ Total } & Number & 9004 & 5006 & 2500 & 7022 & 2500 & 4509 & 3497 & 34038 \\
\hline & $\%$ & 26,5 & 14,7 & 7,3 & 20,6 & 7,3 & 13,2 & 10,3 & 100,0 \\
\hline
\end{tabular}

As a result, the delivery of government services in Russia is associated with the need to provide additional informal preferences that ensure access to these services. Thus, these factors cause the low level of responsibility, confidence and respect between business partners, which is expressed in regular communication failures and violation of agreements, and often provoke conflicts (Auzan et al., 2011).

Table 4. Combination table of responses to the question "In your opinion, do Russian people today live in more agreement, solidarity or disagreement, disunity?"

\begin{tabular}{|l|l|l|l|l|l|l|l|l|l|}
\hline Response options & $\begin{array}{l}\text { Central } \\
\text { FD }\end{array}$ & $\begin{array}{l}\text { Northwes } \\
\text { tern FD }\end{array}$ & $\begin{array}{l}\text { Southern } \\
\text { FD }\end{array}$ & $\begin{array}{l}\text { Volga } \\
\text { FD }\end{array}$ & $\begin{array}{l}\text { Ural } \\
\text { FD }\end{array}$ & $\begin{array}{l}\text { Siberia } \\
\text { n FD }\end{array}$ & $\begin{array}{l}\text { Far } \\
\text { Eastern } \\
\text { FD }\end{array}$ & Total \\
\hline $\begin{array}{l}\text { Definitely in } \\
\text { agreement, } \\
\text { solidarity }\end{array}$ & $\begin{array}{l}\text { Numbe } \\
\text { r }\end{array}$ & 140 & 118 & 68 & 87 & 79 & 122 & 103 & 717 \\
\hline
\end{tabular}




\section{Gamidullaeva}

21

\begin{tabular}{|c|c|c|c|c|c|c|c|c|c|}
\hline \multirow{2}{*}{$\begin{array}{l}\text { Probably in } \\
\text { agreement, } \\
\text { solidarity }\end{array}$} & $\begin{array}{l}\text { Numbe } \\
\mathrm{r}\end{array}$ & 1019 & 792 & 375 & 954 & 306 & 556 & 700 & 4702 \\
\hline & $\%$ & 21,7 & 16,8 & 8,0 & 20,3 & 6,5 & 11,8 & 14,9 & 100,0 \\
\hline \multirow{2}{*}{$\begin{array}{l}\text { Probably in } \\
\text { disagreement, } \\
\text { disunity }\end{array}$} & $\begin{array}{l}\text { Numbe } \\
\mathrm{r}\end{array}$ & 3947 & 2269 & 1074 & 3215 & 1018 & 1917 & 1432 & $\begin{array}{l}1487 \\
2 \\
\end{array}$ \\
\hline & $\%$ & 26,5 & 15,3 & 7,2 & 21,6 & 6,8 & 12,9 & 9,6 & 100,0 \\
\hline \multirow{2}{*}{$\begin{array}{l}\text { Definitely in } \\
\text { disagreement, } \\
\text { disunity }\end{array}$} & $\begin{array}{l}\text { Numbe } \\
\mathrm{r}\end{array}$ & 3171 & 1236 & 782 & 2109 & 824 & 1432 & 854 & $\begin{array}{l}1040 \\
8\end{array}$ \\
\hline & $\%$ & 30,5 & 11,9 & 7,5 & 20,3 & 7,9 & 13,8 & 8,2 & 100,0 \\
\hline \multirow[t]{2}{*}{ Not sure } & $\begin{array}{l}\text { Numbe } \\
\text { r }\end{array}$ & 723 & 591 & 201 & 654 & 273 & 482 & 407 & 3331 \\
\hline & $\%$ & 21,7 & 17,7 & 6,0 & 19,6 & 8,2 & 14,5 & 12,2 & 100,0 \\
\hline \multirow[t]{2}{*}{ Total } & $\begin{array}{l}\text { Numbe } \\
\mathrm{r}\end{array}$ & 9004 & 5006 & 2500 & 7022 & 2500 & 4509 & 3497 & \begin{tabular}{|l|}
3403 \\
8 \\
\end{tabular} \\
\hline & $\%$ & 26,5 & 14,7 & 7,3 & 20,6 & 7,3 & 13,2 & 10,3 & 100,0 \\
\hline
\end{tabular}

As an indicator for the level of collectivism in the Russian regions, we took positive answers (very frequently, frequently) to the question: "How often can you find people around you, who are willing to unite in order to solve problems that do not concern them personally?" (Table 5). The study was conducted by the Public Opinion Foundation "Georating" in the 68 constituent entities of the RF.

Table 5. Combination table of responses to the question "How often can you find people around you, who are willing to unite in order to solve problems that do not concern them personally?'"

\begin{tabular}{|l|l|l|l|l|}
\hline Response options & Frequency & Percent & Nominal percent & $\begin{array}{l}\text { Accumulated } \\
\text { percent }\end{array}$ \\
\hline Very frequently & 361 & 1,1 & 1,1 & 1,1 \\
\hline Frequently & 3204 & 9,4 & 9,4 & 10,5 \\
\hline Rarely & 7736 & 22,7 & 22,7 & 33,2 \\
\hline Very rarely & 10533 & 30,9 & 30,9 & 64,1 \\
\hline Never & 7954 & 23,4 & 23,4 & 87,5 \\
\hline Not sure & 4235 & 12,4 & 12,4 & 100,0 \\
\hline No option & 15 &, 0 &, 0 & 100,0 \\
\hline Total & 34038 & 100,0 & 100,0 & \\
\hline
\end{tabular}

\section{Results}

The analysis of social and cultural background in the development of the RF constituent entities identified four major groups of regions that are similar in several social and cultural development factors. It should be noted that the assessment of the level of a factor is given in comparison with other regions, on the basis of which it is concluded that it is low, average or high.

Regions of the $1^{\text {st }}$ group: the population of these constituent entities displays the greatest willingness to institutional changes, it tends towards entrepreneurial and 
innovative activity, it is characterized by low adherence to the paternalism values, it shows the highest level of interpersonal trust and individualism, and it has confidence in the public authorities (institutional trust).

Regions of the $2^{\text {nd }}$ group: the population of these constituent entities is distinguished by less willingness to institutional changes, it tends towards the paternalism values, it is less inclined to innovative and entrepreneurial activity, it is defined by the lower level of interpersonal trust and individualism, and it has less confidence in the public authorities.

Regions of the $3^{\text {rd }}$ group: the population of these constituent entities is less prepared for institutional changes, it is characterized by the average level of interpersonal trust and the development of individualism, and it trusts in the public authorities to a lesser extent. In addition, the population of these regions is distinguished by its cultural identity, along with the existing religious, ethnic and other features. These circumstances make the processes of institutional changes more complex, so that they require an integrated approach.

Regions of the $4^{\text {th }}$ group: the population of these constituent entities is virtually not ready for institutional reforms, it has a low propensity for innovation, it is defined by high collectivism, low level of both interpersonal trust and confidence in the public authorities, it is less adherent to the paternalism values, and it is defined by ethnic and linguistic diversity and traditional cultural pattern of the population. Therefore, a special approach for the process of institutional change is required. The constituent entities of this group are in the North Caucasus.

If there is an idea of social and cultural background in the development of a specific region, it is necessary to formulate model recommendations before starting the process of institutional changes in the constituent entity (Table 6).

Table 6. Model recommendations prior to institutional changes, considering social and cultural factors of regional development

\begin{tabular}{|l|l|l|}
\hline $\begin{array}{l}\text { Grou } \\
\mathrm{p}\end{array}$ & $\begin{array}{l}\text { Readines } \\
\text { s for } \\
\text { institutio } \\
\text { nal } \\
\text { changes }\end{array}$ & Model recommendations for regions \\
\hline $1^{\text {st }}$ & $\begin{array}{l}\text { High } \\
\text { readiness }\end{array}$ & $\begin{array}{l}\text { These regions may be used as pilot to test certain institutional } \\
\text { changes. The creation of legislation in the region is stimulated, this } \\
\text { legislation is aimed at forming values that motivate development, } \\
\text { encourage the establishment of special economic zones, priority } \\
\text { development areas, etc. Any transformation of institutions carried out } \\
\text { from the top-down will be effective due to the high level of public } \\
\text { confidence in the public authorities. The probability of impeding the } \\
\text { ongoing transformations by social interest groups is low. }\end{array}$ \\
\hline
\end{tabular}




\begin{tabular}{|l|l|l|}
\hline and & $\begin{array}{l}\text { Middle- } \\
\text { high } \\
\text { readiness }\end{array}$ & $\begin{array}{l}\text { In these regions, it is necessary to conduct massive information } \\
\text { campaigns that accompany the process of institutional changes in } \\
\text { order to eliminate the obstruction to these reforms among population } \\
\text { of the regions. In the regions of this group it is advisable to create } \\
\text { specialized interregional organizations involved in promoting } \\
\text { institutional changes, whose functions will be to provide regional } \\
\text { executive bodies with advisory and information support on these } \\
\text { reforms. }\end{array}$ \\
\hline 3rd & $\begin{array}{l}\text { It is advisable to conduct massive advertising campaigns, } \\
\text { emphasizing that the process of institutional changes in the region } \\
\text { does not affect the cultural and religious values specific to the region, } \\
\text { and also aims at eliminating external negative factors of the } \\
\text { innovation environment, for example of climatic or geographical } \\
\text { nature. It is necessary to emphasize all sorts of short-term effects } \\
\text { from the implementation of institutional changes. The process of } \\
\text { institutional changes should take place gradually, since a high degree } \\
\text { of adaptation of the introduced institutions and institutional changes } \\
\text { in the existing social and cultural format of the region is required. }\end{array}$ \\
\hline 4th & $\begin{array}{l}\text { The traditional specific social and cultural factors of the regions of } \\
\text { this group actualize the need to actively inform the population about } \\
\text { the changes being introduced using various media, in particular, the } \\
\text { federal media in local languages. A clear specification of various } \\
\text { benefits and specific effects from the introduced changes, as well as a } \\
\text { clearly defined system of compensation to persons, who may suffer } \\
\text { from the implementation of these changes, is necessary. The process } \\
\text { of transformations in the innovation environment should take place } \\
\text { gradually and undergo open public discussion of all transformations } \\
\text { to reduce the possibility for public obstruction to the institutions } \\
\text { being introduced, as well as opposition among social interest groups. }\end{array}$ \\
readiness
\end{tabular}

\section{Conclusion}

Thus, it has been suggested that in subjects of the RF that demonstrate a low level of economic development, there is a problem of low efficiency in using the existing potential of economic agents and individuals. Such reserves can be formed due to the institutionalization of relevant social practices in these regions, which impede the development of an innovative type of behavior of economic agents and individuals and support a passive type of behavior. On the contrary, in other regions, the established institutions and sociocultural factors (values and attitudes) support and stimulate the innovative type of behavior. At the same time, it is justified that it is extremely important to have a clear idea of a sociocultural background that has developed in a region from the point of view of fine-tuning the process of institutional changes and determining the specifics of conducting them in regions of the Russian Federation.

To take account of the influence of sociocultural factors on the effectiveness of institutional transformations, a system of indicators has been developed, evaluating 
sociocultural characteristics and behavioral attitudes of economic agents in a certain region, based on the classical approach by G. Hofstede. The author developed the model recommendations before starting the process of institutional changes in the concrete regional innovation system.

\section{References:}

Auzan, A.A. 2017. Social and Cultural Factors of Innovative Development and Successful Implementation of Reforms. Moscow.

Auzan, A.A. 2011. Cultural Factors of Modernization. Strategy 2020 Foundation. Moscow and St. Petersburg.

Bouckaert, G. 2007. Cultural Characteristics from Public Management Reforms Worldwide. Chapter 2 in Cultural Aspects of Public Management Reform, 29-64, doi:10.1016/s0732-1317(07)16002-4.

Coase, R. 1993. The Firm, the Market, and the Law. Moscow, Catallaxy.

Demsetz, H. 1995. The economics of the business firm. doi:10.1017/cbo9780511582356.

Eklinder-Frick, J., Eriksson, L.T. \& Hallen, L. 2012. Multidimensional Social Capital as a Boost or a Bar to Innovation. In 28th Industrial Marketing and Purchasing Conference.

Freytag, A. \& Renaud, S. 2007. From short-term to long-term orientation -political economy of the policy reform process. Journal of Evolutionary Economics, 17(4), 433-449.

Gamidullaeva, L. 2018. Towards Combining the Innovation Ecosystem Concept with Intermediary Approach to Regional Innovation Development. International Journal of Economics \& Business Administration, 6(1), 39-53.

Gamidullaeva, L.A., Tolstykh, T.O. 2017. Transaction Costs, Institutions and Regional Innovation Development: The Case of Russia Proceedings of the 30th International Business Information Management Association Conference, 4161-4173, Madrid.

Gamidullaeva, L.A., Vasin, S.M. 2018. The Relationship Between Trust and Knowledge Exchange in Russian Organizations. 19th European Conference on Knowledge Management - ECKM, 286-294, Padua, Italy.

Gorodnichenko, Y., Roland, G. 2011. Which dimensions of culture matter for long-run growth? The American Economic Review, 101(3), 492-498.

Gulyanskaya, E.A. 2008. Individualism and collectivism in the value system of the organizational culture in modern Russia. Bulletin of Stavropol State University, No 56.

Herbig, P.A. \& Miller, J.C. 1993. Culture and technology: Do the traffic move in both directions? Journal of Global Marketing, 6(3), 75-104.

Hofstede, G. 2001. Culture's Consequences: Comparing values, behaviors, institutions, and organizations across nations, 2nd ed., Sage Publications.

Lapin, N.I. 2006. Status of Russian Regions, Unbalanced Sociocultural Functions. World of Russia, 2, 14-41.

Lebedeva, N.M., Tatarko, A.N. 2009. Culture as a factor of social progress. M.: «Yustitsinform» CJSC. $408 \mathrm{p}$.

Menard, C. 2001. Methodological Issues in New Institutional Economics. Journal of Economic Methodology.

Natkhov, T. 2011. Education and Trust in Russia. An Empirical Evidence, 15(3), 353-373.

North, D.C. 1990. Institutions, Institutional Change, and Economic Performance. Cambridge University Press. 
Polterovich, V.M. 2016. Strategies of institutional reforms, or the Art of reforms. Authorities, (5), 146-150.

Popov, E., Sergeev, A. 2010. The Modern Russian Institutionalism: Further Discussion. Voprosy Ekonomiki, 2, https://doi.org/10.32609/0042-8736-2010-2-103-116.

Ruef, M. 2002. Strong ties, weak ties and islands: structural and cultural predictors of organizational innovation. Industrial and Corporate Change, 11(3), 427-449.

Sukharev, O.S. 2013. Methodological Principles of Institutional Analysis: The Old and New Schools and Mainstream. Financial Analytics: Problems and Solutions, 41(179), 1123.

Varsakelis, N.C. 2001. The impact of patent protection, economy openness and national culture on R\&D investment: A cross-country empirical investigation. Research policy, 30(7), 1059-1068.

Vasin, S., Gamidullaeva, L., Shkarupeta, E., Palatkin, I., Vasina, T. 2018. Emerging trends and opportunities for industry 4.0 development in Russia. European Research Studies Journal, 21(3), 63-76.

Waarts, E. \& Van Everdingen, Y. 2005. The Influence of National Culture on the Adoption Status of Innovations: An Empirical Study of Firms Across Europe. European Management Journal, 23(6), 601-610.

Williamson, O.E. 1996. Economic Institutions of Capitalism. Firms, Markets, Relational Contracting. St. Petersburg: Lenizdat.

Woolcock, M. \& Narayan, D. 2000. Social capital: Implications for development theory, research, and policy. The world bank research observer, 15(2), 225-249. 